\title{
The Effect of Caffeine on Mice Recovery Time after Propofol Induction
}

\section{Erlina Rustam ${ }^{1}$, Heniszayanti Nabiladhiya A ${ }^{2}$, Eka Nofita ${ }^{3}$}

${ }^{I}$ Department of Pharmacology and Therapeutic, Faculty of Medicine, Andalas University, Indonesia, ${ }^{2}$ Undergraduate student, Faculty of Medicine, Andalas University, Indonesia, ${ }^{3}$ Department of Parasitology, Faculty of Medicine, Andalas University, Indonesia

\section{ABSTRACT}

The process of recovery from propofol induction sometimes followed by several side effects such as apnea and decreased blood pressure. Moreover, the accumulation of propofol caused by repeated bolus injection could prolong the recovery time. Caffeine has a role as a central nervous system stimulant by enhancing consciousness and awareness. The purpose of this study was to observe the effect of caffeine on recovery time of mice after propofol induction. We divided 24 mice which into 4 groups. Group 1 were induced by propofol alone (control group); while group 2, 3, and 4 was each given caffeine at $0.52 \mathrm{mg}, 0.65 \mathrm{mg}$, and $0.78 \mathrm{mg}$, respectively, prior to propofol induction. The results showed that caffeine administration prior to propofol induction significantly altered mice recovery time (One Way ANOVA, p<0.05). Post-hoc test showed significant difference between control group and each treatment group, however there was no difference between each treatment group ( $\mathrm{p}>0.05)$. It is concluded that caffeine administration prior to propofol induction may influence consciousness recovery time. 